J. Amer. Soc. Hort. Sci. 115(2):234-240. 1990. \title{
Seedling Establishment of Direct-seeded Guayule
}

\author{
J.D. Mihail and S.M. Alcorn \\ Department of Plant Pathology, University of Arizona, Tucson, AZ, 85721 \\ Additional index words. Parthenium argentatum, Pythium dissotocum, Pythium paroecandrum, fungicide, shadecloth
}

\begin{abstract}
The establishment of stands from directly sown seed may be a way to reduce the current high costs associated with guayule (Parthenium argentatum Gray) cultivation. These field studies were conducted to examine the combined effects of shade and fungicides on the survival of guayule seedlings established from directly sown seed. Soil in the experimental plot was a loam of pH 7.25. The following fungicides: a) Terraclor Super X, b) Ridomil 5G, c) Ridomil PC IIG, d) Tilt 3.6E, e) Terracoat, and f) Vitavax + PCNB were tested alone and in combination with the nonwoven polyester shadecloth, Reemay, to identify treatments enhancing seed germination and seedling establishment. In all cases, seedling emergence in microplots covered with Reemay was significantly higher than in noncovered microplots. Terraclor Super X, Ridomil 5G, and Ridomil PC 1 IG were effective only when used in combination with the shadecloth. The long-term survival of guayule seedlings was strongly affected by severe climatic events. Since Reemay-protected seedlings were larger and more robust, they were more likely to survive the climatic extremes than unprotected seedlings. Two new guayule seedling pathogens were recorded -pythium dissotocum Drechsler and $P$. paroecandrum Drechsler. Chemical names used: 5-ethoxy-3-(trichloromethyl)-1,2,4-thiadiazole (Terrazole) + pen. tachloronitrobenzene (PCNB); N-(2,6-dimethylphenyl)-N-(methoxyacetyl)-alamine methyl ester Ridomil + PCNB; 7 . bromo-5-chloro-quinolin-8-yl-acrylate; Terrazole 5,6-dihydro-2-methyl-1,4 -oxathiin-3-carboxanilide + PCNB.
\end{abstract}

Guayule, a latex-producing member of the Composite native to the northern Chihuahua desert of Mexico, was a commercial source of rubber developed by the Emergency Rubber Project (ERP) during World War II (Hammond and Polhamus, 1965).

Received for publication 8 May 1989. Arizona Agricultural Experiment Station Journal Paper 7037. This work was supported by USDA grant 86-CRSR-22755. We gratefully-acknowledge the assistance of M.E. Stanghellini, Dept. of Plant Pathology, Univ. of Arizona, in identification of Pythium species. The cost of publishing this paper was defrayed in part by the payment of page charges. Under postal regulations, this paper therefore must be hereby marked advertisement solely to indicate this fact.

'Present address: Dept. of Plant Pathology, Univ. of Missouri, Columbia, MO 65211.
Recent shortages of natural rubber combined with rising prices of synthetic petrochemical substitutes have again revived interest in this desert shrub.

Historically, guayule stands in the field were established by transplanting seedlings raised in outdoor nurseries or greenhouses (Hammond and Polhamus, 1965). In an effort to reduce production costs, studies initiated during the ERP period explored stand establishment by directly sown seed (Hammond and Polhamus, 1965; Tingey, 1952). Successful seed germination was found to require shallow sowing of seed on finetextured, firm beds with the maintenance of high soil-surface moisture until emergence. Poor survival of these stands was attributed to several problems, including: crusting of soil, damp- 
ing-off diseases at high moisture levels, accumulation of salts at the soil surface, freezing temperatures, damage from wind storms, and weed competition. Pythium ultimum Trow. was probably the most important damping-off pathogen of guayule seedlings growing in the coastal nurseries in California (Campbell and Sleeth, 1945; Mihail et al., 1989). Phytophthora sp. and Rhizoctonia sp. were also found to be pathogenic under the cool, moist conditions of these nurseries (Mihail et al., 1989).

Building on the suggestions of ERP work (Hammond and Polhamus, 1965), several recent studies have demonstrated the efficacy of conditioning treatments in enhancing seed germination (Bucks et al., 1983; Chandra and Bucks, 1986; Fink et al., 1987; Foster et al., 1986a; Naqvi and Hanson, 1980). However, survival of emerged seedlings continues to be reduced by temperature extremes, wind damage, and surface salt accumulation (Foster et al., 1986a; Gonzalez and Rektorik, 1986; Whitworth, 1983). The sensitivity of young guayule seedlings to saline conditions and soil moisture stress has been investigated further by Miyamoto et al. (1984, 1985), who have found optimum seedling emergence only where soil water stress is less than $-80 \mathrm{kPa}$ and the accumulation of surface salts is minimized. The utility of protecting young seedlings either through the use of cover crops or synthetic shade covers has been explored in field studies in Maricopa, Ariz. (Bucks et al., 1987). Synthetic shade covers were found to increase seedling survival by $75 \%$ to $122 \%$ when compared with the wheat cover crop or the unshaded control plots. The benefits of shade materials include reduction of soil and plant temperatures, maintenance of more uniform surface soil moisture, and protection from physical damage (Bucks et al., 1987).

Since the ERP, Pythium aphanidermatum (Edson) Fitzp. (Mihail et al., 1985), Phytophthora cryptogea Pethybridge and Lafferty (Beaupre and Cheo, 1983), and Fusarium oxysporum Schlect. em. Sny. \& Hans. (Mihail et al., 1989) have been added to the list of guayule seedling pathogens in the United States. Two fungi, Fusarium solani (Mast.) Sacc. and Rhizoctonia sp., have been reported as seedling pathogens in India (Mihail et 'al., 1989). In a series of greenhouse studies, Richardson et al. (1985) found that fungicides incorporated into a fluid drilling gel with pregerminated guayule seeds reduced the losses due to pre- and postemergence damping-off caused by Pythium debaryanum Hesse and Rhizoctonia solani Kuhn.

The objectives of the studies described here were to: 1) examine the combined effects of shade and fungicides on guayule establishment following direct seeding, and 2) assess the role of pathogens as constraints to stand establishment.

\section{Materials and Methods}

Field studies. Four field trials were conducted on a Univ. of Arizona experimental farm in Tucson. Field soil was a loam (52\% sand, $33 \%$ silt, and $15 \%$ clay), $\mathrm{pH} 7.25$. Throughout the text, each trial is referred to as SPRING1, SPRING2, FALL, or SPRING3, which reflect seasons of planting and the chronological order of the tests. Each trial was set up as a randomized complete block, using four replicated blocks composed of microplots $1.22 \mathrm{~m}$ long with $0.61 \mathrm{~m}$ separating microplots in the same row. Each combination of fungicide and shade treatments was represented by one microplot in each of four blocks (replications). Raised beds were $1.02 \mathrm{~m}$ apart. Fungicides tested were: a) Terraclor Super X (Uniroyal Chemical, Middlebury, Corm.), b) Ridomil 5G (CIBA-Geigy, Greensboro, N.C.), c) Ridomil PC 11G (CIBA-Geigy), d) Tilt 3.6E (CIBA-Geigy), e) Terracoat (Gustafson, Piano, Texas), and f) Vitavax + PCNB
(Gustafson). The three granular materials (Terraclor Super X, Ridomil 5G, and Ridomil PC 11G) each were thoroughly mixed with $400 \mathrm{ml}$ of white silica sand and spread across the top of the bed immediately following planting. This application technique resulted in a 1- to 2-mm layer of sand on the tops of the treated beds. Tilt $3.6 \mathrm{E}$ was diluted in tap water (1 or 2 liters per microplot for trials FALL and SPRING3, respectively) and applied as a drench immediately following planting. Terracoat and Vitavax + PCNB were both applied as seed treatments. Lots of 100 seeds were mixed with the pre-measured chemical in a clean test tube for $30 \mathrm{sec}$ and $1 \mathrm{rein}$, respectively, The treated seeds were transferred to clean test tubes and stored for 3 days, i.e., until planting.

For trial SPRING1, cheesecloth and the nonwoven polyester material Reemay (Gardener's Supply Co., Burlington, Vt.) were used as protective coverings applied at the time of planting on the soil surface. For the remaining trials, only Reemay was used. The levels of fungicide applied, expressed as amount of formulation, and other experimental treatments are listed in Table 1. In trials SPRING1 and SPRING2, the test treatments were the combination of each cover material with fungicide, each cover material alone, and the fungicide alone. Additionally, the control treatments were sand in combination with each cover material, sand alone, and no cover or fungicide treatment. Thus, there were nine and six treatments in each of the four replicated blocks of trials SPRING1 and SPRING2, respectively. After trial SPRING2, the use of sand controls was eliminated. For trials FALL and SPRING3, the treatments were: each fungicide in combination with Reemay, each fungicide alone, Reemay alone, and no cover or fungicide. Thus, for trial FALL, there were 38 treatments in each of the four complete blocks (Table 1).

For all trials, 100 non-preconditioned seeds of the USDA tetraploid line N565 were hand-planted in each microplot at a depth of 1 to $2 \mathrm{~mm}$. Irrigation of all field trials was a combination of furrow and overhead sprinkler irrigation, beginning on the planting day, and timed to keep the tops of the beds moist during the first 17 to 18 days after planting (Bucks et al., 1986; Zittlosen, 1985). At this time, the cover materials were removed and the first stand counts were made. For trials SPRING1 and SPRING2, the number of healthy seedlings in each microplot was counted daily for 7 days. For trial FALL, stand counts in 1987 were made on Julian days (day of year) 304, 307, 310, $314,321,327$, and 338, and in 1988 on Julian days 4, 11, and 26 (105 days after planting). For trial SPRING3, stand counts were made on Julian days 102, 112, 123, 132, 141, 153, and 162 (78 days after planting). At the end of trial SPRING3, all living plants were harvested by severance at the soil line and oven-dried at 60 to $62 \mathrm{C}$ for 3 days, then weighed at room temperature. Trial SPRING3 was reduced from four to three blocks 30 days after planting due to the destruction of one block by vandals.

Before each field experiment, the viability of the seed was tested by placing 30 non-preconditioned seeds between sheets of moist filter paper in a petri dish and incubating three such petri dishes (replicates) in a growth chamber at 24 to $26 \mathrm{C}$ with a 12-hr light/dark cycle for 5 or 6 days.

Data analysis. For all four trials, all statistical analyses of stand count data were conducted using the $\arcsin \sqrt{\mathrm{p}}$ transformation, where $p$ was the proportion of the original 100 seeds producing healthy seedlings in one microplot. For trials SPRING1 and SPRING2, data were analyzed using two-way analysis of variance (ANOVA) and the least significant difference (LSD) 
Table 1. Experimental treatments for four field trials to enhance guayule seedling establishment.

\begin{tabular}{|c|c|c|c|c|c|}
\hline \multirow{2}{*}{ Treatment } & & \multicolumn{4}{|c|}{ Field trial ${ }^{2}$} \\
\hline & & SPRING1 & SPRING2 & FALL & SPRING3 \\
\hline Planting date & & 31 Mar. 1987 & 28 Apr. 1987 & 13 Oct. 1987 & 24 Mar. 1988 \\
\hline Julian day & & 90 & 118 & 286 & 84 \\
\hline Shade materialy & & $\mathrm{R}, \mathrm{C}$ & $\mathrm{R}$ & $\mathrm{R}$ & $\mathrm{R}$ \\
\hline Removal date & & 17 Apr. 1987 & 15 May 1987 & 31 Oct. 1987 & 11 Apr. 1988 \\
\hline Julian day & & 107 & 135 & 304 & 102 \\
\hline \multicolumn{6}{|l|}{ Fungicide ${ }^{x}$ and level } \\
\hline \multirow[t]{3}{*}{ Super X (g) } & 1 & 9.1 & 18.3 & 4.6 & 2.3 \\
\hline & 2 & & & 9.1 & 4.6 \\
\hline & 3 & & & 18.3 & 9.1 \\
\hline \multirow[t]{3}{*}{ Ridomil 5G (g) } & 1 & & & 0.96 & 0.48 \\
\hline & 2 & & & 1.92 & 0.96 \\
\hline & 3 & & & 2.88 & 1.92 \\
\hline Ridomil & 1 & & & 4.5 & 2.3 \\
\hline \multirow[t]{2}{*}{ PC11G (g) } & 2 & & & 9.1 & \\
\hline & 3 & & & 13.6 & \\
\hline \multirow[t]{3}{*}{ Tilt 3.6E (ml) } & 1 & & & 0.2 & 0.01 \\
\hline & 2 & & & 0.4 & 0.02 \\
\hline & 3 & & & 0.6 & 0.05 \\
\hline \multicolumn{6}{|l|}{ Seed application } \\
\hline \multirow[t]{3}{*}{ Terracoat $(\mathrm{g})$} & 1 & & & 0.05 & \\
\hline & 2 & & & 0.10 & \\
\hline & 3 & & & 0.20 & \\
\hline \multicolumn{6}{|l|}{ Vitavax +} \\
\hline PCNB (\%) & 1 & & & 0.00125 & \\
\hline & 2 & & & 0.0025 & \\
\hline & 3 & & & 0.005 & \\
\hline
\end{tabular}

${ }^{\mathrm{z}}$ Statistical analyses were performed separately for each field trial. Shade material and fungicide were the two main treatments in the ANOVA analyses. All field trials were conducted at the Univ. of Arizona Campbell Ave. Farm in Tucson and involved four replicates per treatment.

${ }^{\mathrm{y}} \mathrm{R}=$ Reemay; $\mathrm{C}=$ cheesecloth.

${ }^{x}$ Fungicides applied as soil treatments are expressed as quantity used per microplot $(1.22 \times 0.25$ $\mathrm{m})$. Fungicides applied as seed treatments are expressed as amounts applied to 100 seeds in test tubes. Super X = Terraclor Super X.

mean separation procedure, where appropriate. For trials FALL and SPRING3, $t$ tests were used for each fungicide treatment to compare plots covered with Reemay with the corresponding unprotected plots. In addition, least-squares regression analysis was used for each fungicide to examine the relationship between the level of the fungicide and the stand of healthy seedlings. A separate regression coefficient was calculated for Reemay-covered and noncovered treatments. In addition, each regression coefficient was calculated both for the inclusion and the omission of the control plots not receiving fungicide treatments. The analysis of the seedling shoot dry weights (trial SPRING3) used $t$ tests to compare Reemay-covered and unshaded treatments for each fungicide.

Pathogens and pathogenicity. The plants from the Tucson tests and from unrelated direct seeding studies in Maricopa (conducted by D. Bucks) were monitored for damage and death. The diseased plants were removed, washed for at least $10 \mathrm{~min}$ in running tap water in the laboratory, blotted dry, then aseptically placed petri dishes containing one of several standard culture media (all in g.liter ${ }^{-1}$ ): WAS (Difco Bacto-agar, 25; streptomycin sulfate, 0.25), CMA (Difco Corn Meal Agar, 17), or PDP (Difco Bacto-Peptone, 10; Difco Potato Dextrose Agar, 39; Difco Bacto-agar, 5, adjusted to $\mathrm{pH} 8.0$ before autoclaving with $1 \mathrm{~N} \mathrm{NaOH}$ ). Culture plates were incubated at 25 or $30 \mathrm{C}$, in the dark, to simulate field temperatures at the time of seedling mortality. Fungal and bacterial isolates of suspected pathogenic activity were maintained in culture until completion of a field trial, when the pathogenicity of the collected organisms was tested. Only those organisms that proved pathogenic in subsequent growth chamber studies were identified further.

All tests of putative pathogens were conducted in growth chambers under light and temperature conditions selected to simulate the weather conditions in the field at the time the test organism was isolated. All pathogenicity tests also used guayule line N565. Two types of pathogenicity tests were conducted with fungal isolates. In the first, 10 or 15 surface-sterilized guayule seeds were placed on petri dishes (three plates per test organism) containing WAS culture medium. After the seeds germinated, the test fungus was introduced onto the plate. The plates were further incubated until the fungus had contacted all seedlings, then the number of dead seedlings in each dish was noted. For the second test, 4-day-old seedlings, growing in vermiculite, were placed in contact with 5- to 8-mm square inoculum blocks of the test fungus. Three pots, each with 15 to 20 seedlings, were used for each target fungus. Plants were watered as needed and observed over a 4- to 7-day period for disease. At least two pathogenicity tests of each type were conducted for each fungal isolate.

For bacterial isolates, several drops of a turbid suspension of the test organism in $4 \mathrm{ml} \mathrm{NB}$ (Difco Nutrient Broth, $4 \mathrm{~g} \cdot$ liter $^{-1}$ ) 
were applied to the cotyledons and apical meristems of 4-dayold seedlings growing in vermiculite. For bacterial isolates recovered from dead plants in trial FALL, suspensions were applied to unwounded seedlings. In contrast, seedlings were wounded with a very fine needle immediately before the application of suspensions of bacteria recovered from diseased plants in trial SPRING3. Three pots, each with 15 to 20 seedlings, were used for each bacterial isolate. All pots were kept in plastic bags to maintain high relative humidity after inoculation and observed during 10 days for disease development. This test was repeated three times for each test organism.

\section{Results}

Field studies. The fungicide Terraclor Super X was not effective in enhancing seedling establishment in trial SPRING1. However, shading the microplots with either cheesecloth or Reemay significantly improved the stand of guayule seedlings when compared with the unshaded control (Table 2). Cheesecloth was difficult to apply and damaged seedlings upon removal; thus, its use was abandoned in subsequent tests. Similarly, the results of trial SPRING2 demonstrated a significant stand enhancement with the use of Reemay, regardless of the fungicide treatment (Table 3). However, in trial SPRING2, there was a significant interaction between fungicide and shade treatments. Of the Reemay-protected treatments, Terraclor Super X was significantly better than the fungicide-absent control, with the sand control intermediate between the two. There was no

Table 2. Average number of healthy guayule seedlings on Julian day 114, 24 days after planting in trial SPRING1.

\begin{tabular}{lcccc}
\hline \hline Shade & $\begin{array}{c}\text { Terraclor } \\
\text { Super X } \\
\text { fungicide }\end{array}$ & $\begin{array}{c}\text { Sand } \\
\text { control }\end{array}$ & $\begin{array}{c}\text { Untreated } \\
\text { control }\end{array}$ & Mean \\
\hline Reemay & 58 & \multicolumn{2}{c}{ No. seedlings ${ }^{2}$} & \\
Cheesecloth & 25 & 45 & 37 & $46.8 \mathrm{a}$ \\
None & 12 & 21 & 20 & $22.3 \mathrm{~b}$ \\
Mean & 31.8 & 15 & 13 & $13.3 \mathrm{c}$ \\
\hline
\end{tabular}

${ }^{z}$ Average of four replicates. Maximum viability of the seeds used in this test was $92 \%$, as determined in a growth chamber test. All statistical analyses were performed on transformed data, as described in the text. Because the interaction term in the ANOVA was nonsignificant, overall means for rows or columns were compared using one-way ANOVA. Overall column means were not statistically different. Overall row means followed by different letters were statistically different at $P \leq 0.05$.

Table 3. Average number of healthy guayule seedlings on Julian day 142, 24 days after planting in trial SPRING2.

\begin{tabular}{lcccc}
\hline \hline & $\begin{array}{c}\text { Terraclor } \\
\text { Super X }\end{array}$ & $\begin{array}{c}\text { Sand } \\
\text { control }\end{array}$ & $\begin{array}{c}\text { Untreated } \\
\text { control }\end{array}$ & LSD (0.05) \\
\hline \multicolumn{5}{c}{ fungicide }
\end{tabular}

${ }^{z}$ Average of four replicates. Maximum viability of seeds used in this test was $92 \%$, as determined in a growth chamber test. For each column, means followed by different letters are statistically different at $P=0.05$. The LSD value is to be used for comparing means within each row at $P \leq 0.05$. Statistical analyses were performed on transformed data as described in the text. such difference among the treatments in uncovered plots. These results suggest that in the presence of Reemay, the sand might give some additional protective benefit (Table 3). Additional experimentation is necessary to determine the mechanism of the interaction between Reemay and sand. Since the sand layer was $<2 \mathrm{~mm}$ thick, it may have been insufficient to promote seedling establishment in the unshaded control plot receiving sand alone (Table 3).

The results of trial FALL (Table 4) again demonstrate a significant stand enhancement in microplots shaded with Reemay when compared with unshaded plots 17 days after planting (when the Reemay was removed). The exceptions were Tilt $3.6 \mathrm{E}$ at levels 1 and 3. The concentrations of Tilt used in trial FALL were highly phytotoxic, resulting in severely stunted guayule seedlings and a complete absence of weeds for the duration of the experiment. When regression coefficients (b) were calculated for each fungicide, omitting the fungicide-absent control, the coefficients generally were not statistically different from $\mathrm{O}$, indicating no difference in stand among the several levels of a fungicide. The exception, Ridomil $5 \mathrm{G}$, had a significant negative coefficient $(\mathrm{b}=-6.4, P \leq 0.05)$, indicating some phytotoxicity by the inverse relationship between fungicide level and guayule stand. When the regression coefficients (b) were recalculated including the fungicide-absent controls, they were significantly positive for Super $\mathrm{X}(\mathrm{b}=1.62, P \leq 0.01)$, Ridomil 5G $(\mathrm{b}=8.05, P \leq 0.05)$, and Ridomil PC $11 \mathrm{G}(\mathrm{b}=$ $2.23, P \leq 0.01)$ applied in combination with Reemay, indicating that these fungicides gave significantly greater stands than the fungicide-absent control. The significant negative coeffi-

Table 4. Average number of healthy seedlings in trial FALL, 17 (Julian day 304, 1987) and 105 (Julian day 26, 1988) days after planting.

\begin{tabular}{|c|c|c|c|c|c|}
\hline \multirow[b]{2}{*}{ Fungicide } & \multirow[b]{2}{*}{ Level } & \multicolumn{2}{|c|}{ JDay 304} & \multicolumn{2}{|c|}{ JDay 26} \\
\hline & & Reemay & $\begin{array}{c}\text { No } \\
\text { shade }\end{array}$ & Reemay & $\begin{array}{c}\text { No } \\
\text { shade }\end{array}$ \\
\hline \multirow[t]{4}{*}{ Terraclor Super X } & \multicolumn{5}{|c|}{ No. seedlings ${ }^{z}$} \\
\hline & 1 & 49.8 & $23.3^{* *}$ & 15.0 & $0.5^{* * *}$ \\
\hline & 2 & 59.5 & $25.5^{* * *}$ & 13.8 & $1.8^{* *}$ \\
\hline & 3 & 55.5 & $22.5^{* * *}$ & 5.3 & $0.5^{* * *}$ \\
\hline \multirow[t]{3}{*}{ Ridomil 5G } & 1 & 61.8 & $31.8^{* * *}$ & 22.0 & $0.5^{* * *}$ \\
\hline & 2 & 55.0 & $36.8 * *$ & 19.0 & $1.3 * * *$ \\
\hline & 3 & 49.5 & $20.5^{* *}$ & 9.5 & 0 \\
\hline \multirow[t]{3}{*}{ Ridomil PC $11 \mathrm{G}$} & 1 & 61.0 & $30.3^{* * *}$ & 8.5 & $1.5^{* *}$ \\
\hline & 2 & 55.8 & $18.0 * * *$ & 7.5 & 0.3 \\
\hline & 3 & 57.0 & $20.8 * * *$ & 9.3 & 0 \\
\hline \multirow[t]{3}{*}{ Tilt $3.6 \mathrm{E}$} & 1 & 6.0 & 2.0 & 0 & 0 \\
\hline & 2 & 6.8 & $0.3^{* * *}$ & 0 & 0 \\
\hline & 3 & 1.3 & 0.5 & 0 & 0 \\
\hline \multirow[t]{3}{*}{ Terracoat } & 1 & 25.5 & 11.3 & 10.0 & $0.3^{* *}$ \\
\hline & 2 & 38.3 & $10.3^{* * *}$ & 10.0 & 0 \\
\hline & 3 & 31.3 & $11.8 * * *$ & 6.8 & 0 \\
\hline \multirow[t]{3}{*}{ Vitavax + PCNB } & 1 & 27.3 & $8.8^{* * *}$ & 3.8 & 0 \\
\hline & 2 & 20.5 & $11.3^{* *}$ & 3.5 & 0 \\
\hline & 3 & 26.0 & $9.3^{* *}$ & 4.8 & 0 \\
\hline None & & 21.5 & $8.8^{*}$ & 6.3 & $0.5^{* *}$ \\
\hline
\end{tabular}

"JDay is Julian day (day of year). Average of four replicates. Maximum viability of the seeds used in this test was $73 \%$, as determined in a growth chamber test.

$\because, \because, * *$ Two means for the indicated fungicide treatment were statistically different at $P \leq 0.06,0.05$, and 0.01 , respectively, using a $t$ test on data transformed as described in the text. No statistical test was possible where one mean (and the associated variance) was zero, because the implicit assumption of homogeneity of variance was violated. 
cients for Tilt with $(\mathrm{b}=-30.0, P \leq 0.01)$ or without $(\mathrm{b}=$ - 13.3, $P \leq 0.01)$ Reemay demonstrated the depression of seedling emergence as a result of fungicide phytotoxicity. With this exception of Tilt, when Reemay was not used, the guayule stand was the same in fungicide-treated and fungicide-absent plots, as demonstrated by the nonsignificant regression" coefficients.

Survival of established seedlings in trial FALL was dramatically affected by the advent of freezing temperatures beginning on 20 Nov. 1987 (Julian day 320) and continuing intermittently throughout the remainder of the study. The rapid stand decline and associated air temperatures are illustrated for two treatments in Fig. 1. In general, those seedlings that were most robust at the beginning of the freezing weather were most likely to survive. Seedlings in plots covered with Reemay were usually larger than those in unprotected plots. The reduction of stand resulting from the prolonged cold weather can be seen in the stand data 105 days after planting (Julian day 26, 1988) (Table 4). The significant enhancement of the stand was still evident for Reemay-covered plots receiving the Terraclor Super X (all levels), Ridomil 5G (all levels), and Ridomil PC 11G (level 1) fungicide treatments, and in the fungicide-absent control (Table 4), although the additional benefits of fungicides were not evident as their regression coefficients were nonsignificant.

Eighteen days after planting trial SPRING3 (Julian day 102), the guayule stands were significantly greater in all plots covered with Reemay than in all nonshaded plots (Table 5). None of the regression coefficients were significantly different from zero, irrespective of the method of calculation, implying that for each fungicide there were no differences in stand among the various concentrations. Additionally, within each cover treatment, there

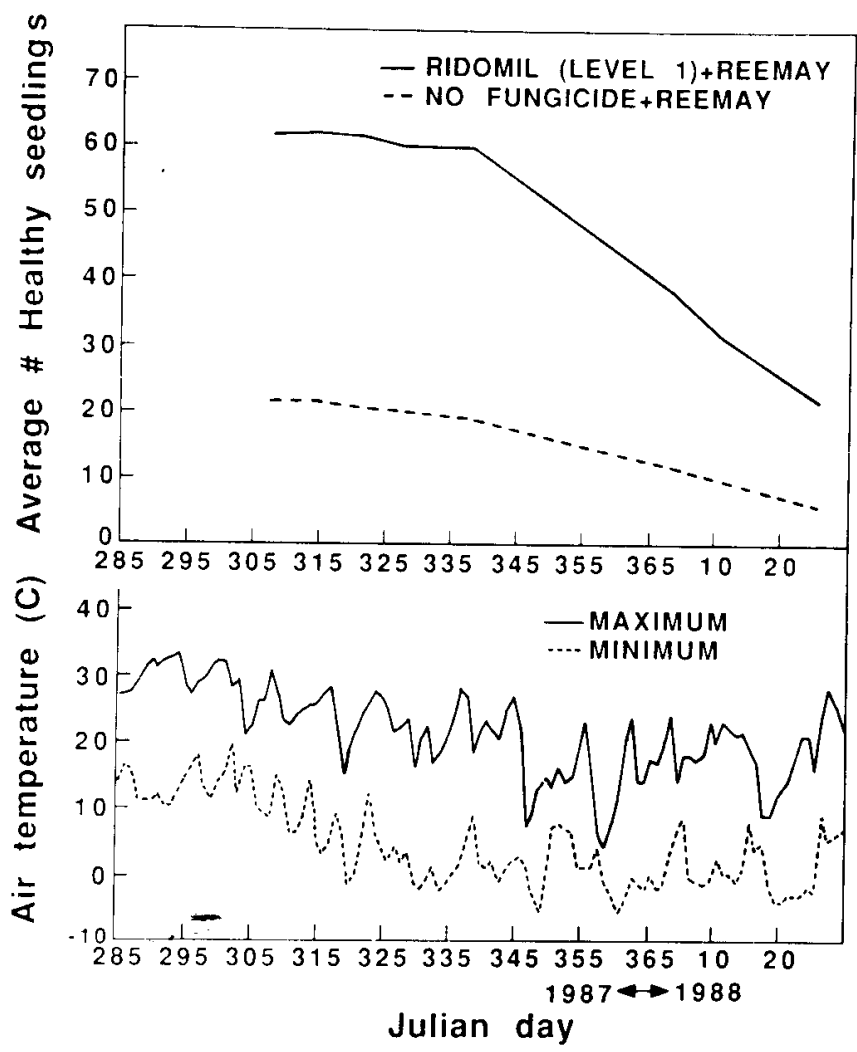

Fig. 1. Seedling survival for selected treatments in trial FALL. (Top) Average of four replicates. (Bottom) Daily maximum and minimum air temperatures $\left({ }^{\circ} \mathrm{C}\right)$.
Table 5. Average number of healthy seedlings in trial SPRING3, 18 (Julian day 102) and 78 (Julian day 162) days after planting.

\begin{tabular}{lccccc}
\hline \hline & & \multicolumn{2}{c}{ JDay 102 } & \multicolumn{2}{c}{ JDay 162 } \\
\cline { 3 - 6 } Fungicide & Level & Reemay & $\begin{array}{c}\text { No } \\
\text { shade }\end{array}$ & Reemay & $\begin{array}{c}\text { No } \\
\text { shade }\end{array}$ \\
\hline \hline \multirow{2}{*}{ Terraclor Super X } & 1 & 51.5 & $14.5^{* *}$ & 10.3 & 3.3 \\
& 2 & 56.3 & $7.3^{* *}$ & 26.3 & 0.7 \\
Ridomil 5G & 3 & 51.3 & $5.5^{* *}$ & 6.0 & $0.3^{*}$ \\
& 1 & 53.3 & $11.8^{* *}$ & 37.3 & 0.7 \\
Ridomil PC11G & 2 & 56.0 & $12.0^{* *}$ & 31.0 & 1.3 \\
Tilt 3.6E & 3 & 54.8 & $8.5^{* *}$ & 15.0 & 0.7 \\
& 1 & 61.0 & $9.8^{* *}$ & 20.3 & 1.7 \\
None & 1 & 8.8 & $2.0^{*}$ & 2.7 & 1.3 \\
& 2 & 11.5 & $1.8^{* *}$ & 6.3 & 2.7 \\
& 3 & 13.3 & $2.0^{*}$ & 8.7 & $0^{\text {y }}$ \\
& & 38.0 & $3.3^{* *}$ & 15.0 & 0.7 \\
\hline
\end{tabular}

${ }^{2}$ JDay is Julian day (day of year). Average of four and three replicates at days 18 and 78, respectively. Maximum viability of the seeds used in this test was $79 \%$, as determined in a growth chamber test.

'Indicates no statistical test was possible where one of the means (and the associated variance) was zero, because the implicit assumption of homogeneity of variances was violated.

Two means for the indicated fungicide treatment were statistically different at $P \leq 0.05$ and 0.01 , respectively, using a $t$ test on transformed data as described in the text.

was no statistical difference between fungicide-present and fungicide-absent treatments. Beginning on 25 Mar. 1988, the day after planting, unusually hot, dry winds persisted for several days, making the maintenance of uniform surface soil moisture difficult. This resulted in the large variability in stand data within treatments. On 15 and 16 Apr. 1988 (Julian days 106 and 107), thunderstorms caused extensive injury to the seedlings both from the mechanical damage of the splashing soil particles and by coating seedlings with a fine layer of mud that formed a hard encasement upon drying. The effect of this latter event on seedling survival is illustrated for two treatments in Fig. 2. Seedlings surviving the 2 days of rain generally survived for the remainder of the study. The slight stand increase apparent in this figure may be explained by a delay of 20 to 30 days in the germination and emergence of some seeds. Again, seedlings in microplots protected by Reemay were generally larger and more robust and were more likely to survive the severe weather. The seedling stand at the end of the study, 78 days after planting, is summarized in Table 5 (Julian day 162). At this time, all remaining seedling shoots were removed from the field, oven-dried, and weighed (Table 6). These shoot dry weight data support the observations that Reemay-protected seedlings were more robust than unprotected seedlings.

Pathogens and pathogenicity. During the course of these studies, and in the monitoring of the experimental plots at Maricopa, isolations for pathogenic organisms were made from $\approx 300$ dying seedlings. The symptoms expressed by virtually all dying seedlings were the same. Necrosis began at the outer margins of the cotyledons and progressed inward to the apical meristem. Frequently, the hypocotyl was coated with dried mud splashed from rain or from sprinkler irrigation. When this mud was removed, the hypocotyls and roots were healthy.

Of the 64 bacterial isolates tested, none proved pathogenic under the conditions used. Of the 40 fungal isolates tested, all Pythium spp. were pathogenic. $P$. paroecandrum Drechsler was recovered from one diseased seedling in trial SPRING1 and 


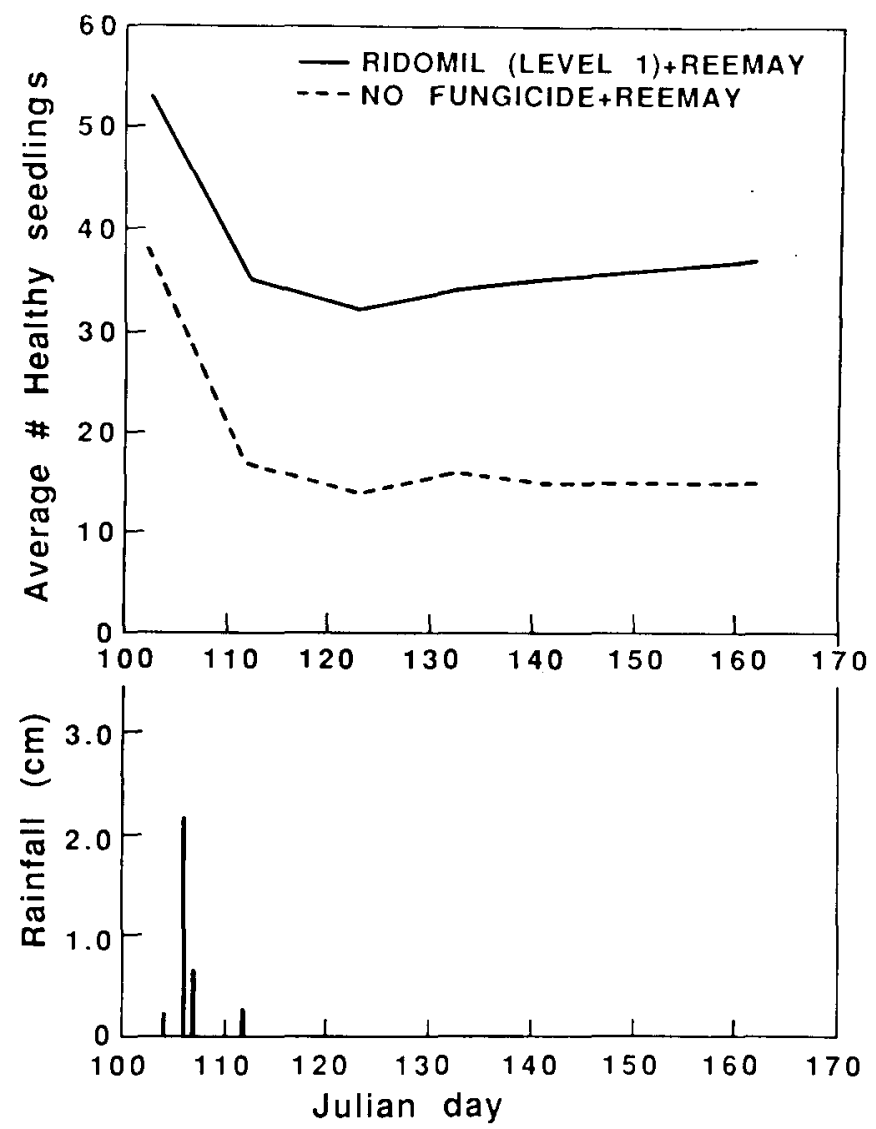

Fig. 2. Seedling survival for selected treatments in trial SPRING3. (Top) Average of four replicates. (Bottom) Daily rainfall.

Table 6. Average dry weights of surviving guayule plants at the end of trial SPRING3.

\begin{tabular}{lcccr}
\hline \hline & \multicolumn{4}{c}{ Plant dry wt $(\mathrm{g})^{\mathrm{z}}$} \\
\cline { 2 - 5 } Fungicide & Reemay & $\mathrm{n}$ & No shade & $\mathrm{n}$ \\
\hline Terraclor Super X & 1.27 & 128 & $0.50^{* *}$ & 13 \\
Ridomil 5G & 1.02 & 250 & $0.20^{* *}$ & 8 \\
Ridomil PC 11G & 1.31 & 61 & $0.08^{* *}$ & 5 \\
Tilt 3.6E & 1.01 & 53 & $0.29^{* *}$ & 12 \\
None & 1.52 & 45 & 0.86 & 2 \\
\hline
\end{tabular}

${ }^{z} n$ is the number of plants comprising the average. The weights of all plants receiving a particular fungicide were combined, regardless of the concentration of the fungicide applied.

**Two means for the indicated fungicide were statistically different at $\mathrm{P} \leq 0.01$ using a $t$ test.

killed $67 \%$ of seedlings in growth chamber pathogenicity tests. This pathogen was also recovered in Jan. 1984 from 42 of $\approx 100$ diseased, 3-month-old seedlings growing in an experimental plot with high mortality, in Yuma, Ariz., in a soil with 800 to 1550 ppm soluble salts (unpublished data). Pythium dissotocum Drechsler was recovered from only one diseased seedling in trial SPRING3 and it killed $65 \%$ of seedlings in pathogenicity tests. $P$. aphanidermatum, recovered from four of 11 seedlings in experimental plots at Maricopa, has previously been reported from diseased guayule seedlings (Mihail et al., 1985). (This fungus killed $86 \%$ of guayule seedlings in growth chamber pathogenicity tests. ) Other fungal genera were frequently recovered from drying seedlings, but none proved pathogenic. These in- cluded Alternaria, Curvularia, Drechslera, Fusarium, and Stemphyllium.

\section{Discussion}

At present, an effective stand of guayule is estimated to range from 25,000 to 50,000 mature plants per hectare (Fangmeier et al., 1984). Attaining such numbers by direct seeding on unshaded beds does not seem feasible. Based on observations and available data on direct seeding, the establishment processes for guayule can be divided into two phases. The first occurs over the first 2 to 3 weeks following seeding and includes the germination and initial establishment of seedlings during the period of high soil moisture. The second covers the 2 to 3 months following the first phase, a period during which irrigation frequencies are being reduced.

Clearly, germination and initial establishment during phase one can be significantly enhanced by the use of Reemay or a similar material, which confirms the results of Bucks et al. (1987). In fact, if the best stand establishments given in Tables 2-5 for the 17 to 24 days following seeding were expressed as percentages of viable seeds (Whitvorth, 1983), they would range from $\approx 60 \%$ to $84 \%$. The benefits of fungicide applications are only apparent in the results from the shade tests. Of the most effective chemicals, the basic component of Ridomil is particularly effective against Oomycetes, as is one of the constituents of Terraclor Super X. Their effectiveness in these tests probably relates to the fact that diseases associated with Oomycetes are also commonly associated with high levels of soil moisture. One unresolved problem with Reemay is that it also enhances establishment of weeds. One area for further research is the identification of a selective herbicide for use in conjunction with Reemay. A major consideration in the exploitation of this technique is the determination of the cost-effectiveness of the application of shading material. Should Reemay prove too costly, alternative shading materials and/or novel cover crops will need to be identified. The development of economically feasible shading alternatives will be hastened by an understanding of the mechanism by which Reemay enhances germination and seedling establishment. Bucks et al. (1987) suggested that shading reduced plant and soil temperatures and promoted the maintenance of surface soil moisture. Additional research should also address the effect of shading on the quantity and quality of light available to guayule seedlings.

Several researchers have noted that guayule seedling mortality increases after the first several weeks following seeding (phase 2) (Bucks et al., 1986; Foster et al., 1986b; Whitworth, 1983). The data presented here (Tables 4 and 5) substantiate these observations. In fact, the fungicide efficacy that was noted earlier is essentially a moot factor because of the mortality during this period. Thus, although it does appear that an adequate initial stand can be established by direct seeding through the use of good-quality seeds, fungicides, adequate moisture, and shade, research must be focused on enhancing survival during phase two to make even the shading technique practical.

Although two previously undescribed pathogens of guayule were noted (Pythium dissotocum and P. paroecandmm), their importance in these studies was minor, but they are worth noting as they expand the reported list of guayule pathogens. However, since $P$. paroecandrum has caused mortality among 3-monthold plants in Yuma, Ariz., under some circumstances, this fungus may constrain the establishment of guayule stands from seeds sown directly.

In ERP studies of seedling establishment, damping-off dis- 
eases played a large role in seedling mortality (Campbell and Sleeth, 1945; Mihail et al., 1989). The relatively minor contribution of previously described pathogens to seedling mortality in the present studies may be attributable to the differences in aridity between coastal California and southern Arizona. The conditions encountered in Arizona are probably more typical of those environments where guayule will be most widely cultivated in the future.

\section{Literature Cited}

Beaupre, C.M.S. and P.C. Cheo. 1983. Phytophthora root rot disease and other pests of guayule culture, p. 477-482. In: E.C. Gregg, J.L. Tipton, and H.T. Huang (eds.). Proc. 3rd Intl. Guayule Conf., Pasadena, Calif.

Bucks, D. A., D.A. Dierig, G.R. Chandra, R.A. Backhaus, R.L. Roth, and S.M. Alcorn. 1983. Progress in direct seeding of guayule. 4th Annu. Conf., Guayule Rubber Soc., Riverside, Calif. (Abstr.)

Bucks, D. A., D.E. Powers, G.R. Chandra, S.G. Allen, and D.H. Fink. 1987. Shading techniques for the direct seeding of guayule. 7th Annu. Conf., Guayule Rubber Sot., 2-6 Nov. Annapolis, Md. (Abstr.)

Bucks, D. A., R.L. Roth, D.E. Powers, and G.R. Chandra. 1986. Direct seeding for economical guayule field establishment, p. 7787. In: D.D. Fangmeier and S.M. Alcorn (eds.). Proc. 4th Intl Conf. Guayule Res. Dev. Tucson, Ariz.

Campbell, W.A. and B. Sleeth. 1945. A root rot of guayule caused by Pythium ultimum. Phytopathology 35:636-639.

Chandra, G.R. and D.A. Bucks. 1986. Improved quality of chemically treated guayule (Parthenium argentatum Gray) seeds, p. 59-68. In: D.D. Fangmeier and S.M. Alcorn (eds.). Proc. 4th Intl. Conf. Guayule Res. Dev. Tucson, Ariz.

Fangmeier, D.D., D.D. Rubis, B.B. Taylor, and K.E. Foster. 1984. Guayule for rubber production in Arizona. Univ. of Ariz., Agr. Expt. Sta., Tech. Bul. 252.

Fink, D.H., S.G. Allen, D.A. Bucks, F.S. Nakayama, D. Powers, and K. Patterson. 1987. Guayule seedling emergence as related to planting depth. 7th Annu. Conf., Guayule Rubber Sot., 2-6 Nov. Annapolis, Md. (Abstr.)

Foster, M.A., T.D. Carrillo, and J. Moore. 1986a. Direct seeding of guayule in west Texas, p. 71-75. In: D.D. Fangmeier and S.M. Alcorn (eds.). Proc. 4th Intl. Conf. Guayule Res. Dev. Tucson, Ariz.

Foster, M.A., D.W. Ranne, and J. Moore. 1986b. Establishment of guayule by direct seedling. 6th Annu. Conf., Guayule Rubber Co., 8-10 Oct. College Station, Texas. (Abstr.)

Gonzalez, C.L. and R.J. Rektorik. 1986. Direct seeding of guayule under dryland conditions, p. 69. In: D.D. Fangmeier, and S.M. Alcorn (eds.). Proc. 4th Intl. Conf. Guayule Res. Dev. (Abstr.)

Hammond, B.L. and L.G. Polhamus. 1965. Research on guayule (Parthenium argentatum): 1942-1959. USDA Tech. Bul. 1327.

Mihail, J.D., S.M. Alcorn, and P.J. Thrapp. 1985. First report of Pythium aphanidermatum infecting guayule. Plant Dis. 69:177.

Mihail, J.D., S.M. Alcorn, and J.W. Whitworth. 1989. Plant health: The interactions of guayule, microorganisms, arthropods, and weeds. In: J.W. Whitworth and E.E. Whitehead (eds.). Guayule Natural Rubber. G.A.M.C. and USDA/CSRS Publishers. (In press.)

Miyamoto, S., K. Piela, J. Davis, and L.B. Fenn. 1984. Salt effects on emergence and seedling mortality of guayule. Agron. J. 76:295300.

Miyamoto, S., K. Piela, and J. Petticrew. 1985. Salt effects on germination and seedling emergence of several vegetable crops and guayule. Irr. Sci. 6:159-170.

Naqvi, H.H. and G.P. Hanson. 1980. Recent advances in guayule seed germination procedures. Crop Sci. 20:501-504.

Richardson, J. M., J.C. Stutz, and R.A. Backhaus. 1985. Incorporating fungicides into fluid drilling gel to control damping off of guayule. HortScience 20:717-719.

Tingey, D. 1952. Effect of spacing, irrigation, and fertilization on rubber production in guayule sown directly in the field. Agron J. 44:298-302.

Whitworth, J.W. 1983. Seed quality, field seedling and plant survival of guayule. El Guayulero 5(1):7-9.

Zittlosen, R.H. 1985. Establishment of directly seeded guayule using sprinkler irrigation. MS Thesis, Univ. of Arizona, Tucson. 